\title{
Sciendo
}

\section{Impact of Fraud Risk Assessment on Good Corporate Governance: Case of Public Listed Companies in Oman}

\author{
Ali Rehman \\ Internal Audit Department, A'Sharqiyah University, Sultanate of Oman \\ Fathyah Hashim \\ Graduate School of Business, Universiti Sains Malaysia, Malaysia
}

\section{Abstract}

Background: Fraud risk assessment as a control mechanism is becoming necessary due to continuous and never-ending fraudulent activities. Frauds arise regardless of the existence of codes for corporate governance and available control activities such as those of internal and external audit units. It is high time for the corporate governance functions such as Audit and Risk Committees and Senior Management to identify the controls, which can assist in achieving good corporate governance and at the same time provide satisfaction to the shareholders. Objective: This paper intends to identify the relationship between fraud risk assessment and good corporate governance of companies listed in the Muscat Stock Market in the Sultanate of Oman. Methods/Approach: A quantitative method with a descriptive cross-sectional survey design has been utilized and data have been analysed by utilizing PLS-SEM. Result: Fraud risk assessment has a significant direct impact on good corporate governance, and the adoption and implementation of the fraud risk assessment will assist in the achievement of good corporate governance. Conclusion: It is highly recommended that organizations adopt fraud risk assessment as fraud detection, control mechanism, and embed it in their corporate governance policies, which will eventually aid in the achievement of good corporate governance.

Keywords: fraud risk assessment, good corporate governance, corporate governance, audit, and risk committee, senior management

JEL classification: G3, G34

Paper type: Research article

Received: Nov 09, 2018

Accepted: Jan 26, 2019

Citation: Rehman, A., Hashim, F. (2020), "Impact of Fraud Risk Assessment on Good Corporate Governance: Case of Public Listed Companies in Oman", Business Systems Research, Vol. 11 No. 1, pp. 16-30.

DOI: 10.2478/bsrj-2020-0002

\section{Introduction}

Organizations that contend and dealt with frauds such as Bank Muscat, Oman national gas, Enron, Satyam, and WorldCom necessitated the enhanced focus on controls related to fraud, which includes fraud risk assessment (Bhasin, 2013; Singleton \& Singleton, 2010). Several committees and ordinances have been created after the 
occurrence of fraud; however, according to ACFE (2016) fraud amounts and number fraud encountered organizations are increasing every year. These ever-increasing frauds are occurring despite the fact of the availability of controls and codes of corporate governance. Moreover, it is high time for organizations to develop antifraud controls and provide innovation in the field of corporate governance (Singleton \& Singleton, 2010). This innovation in controls could have termed as fraud risk assessment and innovation in corporate governance can be called as the realization and accomplishment of good corporate governance.

Several kinds of literature are available, which emphasizes on the implementation of corporate governance; moreover, compliance with the codes of corporate governance is also made mandatory by many regulators, including Capital Market Authority (CMA) in Oman (CMA, 2016). However, in the current business environment, corporate governance is just becoming a compliance checkbox (Abdel-Meguid, Samaha \& Dahawy, 2014; Rehman \& Hashim, 2019).

Organizations are adopting corporate governance for the sake of disclosure purposes, and the governance management system responsible for corporate governance appears to be of least concern. For this study, governance management is considered to be Audit and Risk Committee (ARC) and Senior Management (SM) of the organization as $A R C$ is directly responsible towards the risk of fraud and $S M$ is directly responsible towards the implementation of policies and detection of fraud (Rehman \& Hashim, 2019; Mohd-Sanusi, Rameli, Omar, \& Ozawa, 2015). Corporate governance is relatively new in Oman, as new codes have been introduced in the year 2016 (CMA, 2016). Moreover, very few studies are available, which can be related to Oman's corporate governance. It is worth mentioning that, like any other country, Oman is also not safe regarding fraud. Few fraud cases were reported in Oman that can be categorized as bribery and financial misconduct frauds (Reuters, 2014; Reuters, 2011 ). At present, there are no guidelines available in Oman, which can determine that corporate governance is good or can be categorized as poor.

This study proposes that Fraud Risk Assessment (FRA), which is the independent variable, possesses a direct relationship with good corporate governance (GCG), which is the dependent variable. FRA is the cornerstone of fraud risk management and plays a vital role in shaping an organization's objectives, strategies, and goals. Furthermore, FRA also assists in the achievement of the true meaning of corporate governance (KPMG, 2014). This study also attempts to integrate relevant empirical research and literature to extend the intended potentials of FRA on GCG, particularly in Omani public listed companies. Corporate governance is contingent upon many constituents, and two of the crucial constituents or factors are ARC and SM (Wilkinson \& Plant, 2012; CMA, 2016). It is worth mentioning that the available past studies demonstrate a single constituent relationship with GCG and not with primary two, which are ARC and SM. Therefore, this study is unique in its way by testing two significant components or constituents towards GCG.

\section{Literature Review}

Corporate governance is an inevitable part of any Omani public listed companies (CMA, 2016). Rules to establish an organization are framed in a manner that obliges the organization to adhere to the basic and essential requirements of corporate governance such as having the board of directors, creating board related committees and hiring SM (Vona, 2010). However, organizations are just utilizing corporate governance as another compliance tool rather than implementing it as a strategic initiative towards sustainable future growth. Fraud is the primary cause where organizations not only suffer from financial losses but also lose their credibility and 
reputation (Gatzert, Schmit, \& Kolb, 2016). Achievement of GCG with the implementation of FRA can provide sustainable growth that can be free from fraud and can offer satisfaction to shareholders.

\section{Good corporate governance}

Poor corporate governance ensures the collapse of an organization as it can encounter fraud, bankruptcy and even closure of the organization (Nwagbara, 2012). A similarity to corporate governance, GCG is also dependent on legislation including well-defined board culture that can safeguards policies and processes (Homayara, Md. Jahangir, Saeed, \& Sawlat, 2008). GCG provides vital and critical steps for market confidence and encourages sustainable investments (Pintea \& Fulop, 2015). Because of GCG, market confidence enhances, stakeholders' support increases, which eventually affects positively in nourishing business and prolonging business sustainability. GCG ensures sustainable long-term growth and development, creates foundations that incorporate regulated board and accuracy and reliability in financial reporting. GCG assists in implementation of laws and regulations, system of responsibility and accountability, protecting the interest of minority shareholders and with GCG organizations realizes their optimum efficiency and effectiveness by mitigating fraud and exploitation of power (Homayara et al., 2008; Hashim, Mahadi \& Amran, 2015). As mentioned earlier, the existence of organizations is subjected to the availability of corporate governance; however, it is dependent upon the board of directors and related committees and SM to achieve corporate governance in a manner that can be considered as good or bad. GCG augments the organizational values, and on the other hand, poor governance performs the opposite. Table 1 defines the principles of GCG (Oso \& Semiu, 2012).

\section{Table 1}

Principals of good corporate governance

\begin{tabular}{|c|c|}
\hline $\begin{array}{l}\text { Principals of Good Corporate } \\
\text { Governance }\end{array}$ & Description \\
\hline $\begin{array}{l}\text { Shareholders rights along with } \\
\text { unbiased treatment }\end{array}$ & $\begin{array}{l}\text { Fundamental rights and entitlements should be provided to } \\
\text { shareholders. These rights are required to be adequately } \\
\text { articulated and available in the organizational charter and } \\
\text { also on its website. Shareholders, regardless of their number } \\
\text { of shareholding, are needed to be treated equally. }\end{array}$ \\
\hline Interest of stakeholders & $\begin{array}{l}\text { Approved policies and processes should exist towards the } \\
\text { protection of stakeholders' interests. }\end{array}$ \\
\hline $\begin{array}{l}\text { Board of director's roles and } \\
\text { responsibilities }\end{array}$ & $\begin{array}{l}\text { Formation of the board and its related roles and } \\
\text { responsibilities should be formally available in terms of } \\
\text { reference or board's charter. Composition of the board } \\
\text { members should be made in a manner that the greater } \\
\text { percentage of the board members should have capability } \\
\text { and knowledge which can directly be attributable to } \\
\text { organizational business, accounting, and auditing. }\end{array}$ \\
\hline Ethical behavior and Integrity & $\begin{array}{l}\text { This is elementary for GCG. Board members and senior } \\
\text { management are required to perform with ethics and } \\
\text { integrity. Conflict of interest should be avoided and duty } \\
\text { should be performed with due professional care. }\end{array}$ \\
\hline Transparency and disclosure & $\begin{array}{l}\text { Organizations must provide complete and proper } \\
\text { disclosures in financial statements. Organizations are also } \\
\text { obliged to give all related parties transactions }\end{array}$ \\
\hline
\end{tabular}

Source: Oso and Semiu (2012) 
For the achievement of the above-mentioned principals, ARC and SM play a significant role. These two constituents of GCG are explained below.

\section{Audit and risk committee}

ARC are persons who ensure that SM has strong and active internal controls and also have systems of risk management aiming towards the safeguarding of shareholders' interests and organization's assets (CMA, 2016). ARC performs a vital role in the establishment of corporate governance and the achievement of GCG. The success of ARC is dependent upon their regulating responsibility and their working involvement with other constituents of corporate governance, which includes board of directors, SM, internal auditors, and external auditors (Abdel-Meguid, Samaha \& Dahawy, 2014; Wilkinson \& Plant, 2012; Rezaee, Daniel, Ha \& Suen, 2016).

There are no mandatory requirements for the formation of ARC; however, by CMA (2016), ARC members should be comprised of people who are independent and should be present in the board of directors. Minimum number of ARC members should be three who should be well versed in the field of accounting, auditing and fraud (CMA, 2016; Zakaria, 2012)

For the achievement of GCG, ARC is required to be majorly engaged in oversight of anti-fraud programs and recommendations for the approval of financial policies (Singleton \& Singleton, 2010). Furthermore, the ARC's effectiveness is also dependent upon its number of effective meetings and its related frequencies (Shir, 2013). Meetings of ARC should be conducted in a manner that covers and reflects business necessities and its associated requirements (Al-Moataz, 2003). Effective ARC meetings reduce the organizational risk and can also enhance corporate governance (Stewart \& Munro, 2007; Wilkinson, 2014, Mohd-Sanusi et al., 2015) that can eventually lead towards the attainment of GCG.

ARC directly reports to the board of directors and also presents its internal control disclosure in organizations' financial statements. ARC deals with matters such as ensuring strategic plans alignment with organizational objectives, finance, and risk management system, internal and external audit and transparency of an organization's performance (Krishnan \& Lee, 2008). Furthermore, it is determined by Efiong (2012) and Abbot, Park, and Parker (2000) that the current ARC reduces fraud elements and assists in enhancing corporate governance.

For ARC to be capable and contribute towards the achievement of GCG, internal and external auditors should directly report to ARC (Hoitash \& Hoitash, 2009; CMA, 2016; Saud \& Marchand, 2012). The ARC should formally discuss the audit reports and its related findings or observations with SM. These discussion obliged SM to implement recommendations suggested by internal and external auditors which ultimately reduces the risk and improve organizational performance (García et al., 2010; Laux \& Laux, 2009)

The ARC should possess the knowledge and should have expertise which can identify fraud-related risk and highlight these to the board of directors' attention. Even though ARC does not have the authority to approve, but its assuring role can ensure that an organization's strategies and objectives are free from risk, elements of fraud are highlighted, reported and mitigated for the achievement of the better-governed organization (Bentley-Goode, Newton \& Thompson, 2017; Wilbanks, Hermanson \& Vineeta, 2017).

\section{Senior management}

It is a widely known fact that without positive support of SM, frauds are more likely to occur. Moreover, SM is required to provide support for financial reporting, fraud 
prevention and the implementation of the strategic plan (Weber, 2010; Bruisnsma \& Wemmenhove 2009). SM is supposed to set the tone at the top, which can be further defined as the culture of ethics and integrity developed and adopted by SM. Once this tone is set, it drilled down to the whole of the organization (Brennan \& McGrath, 2007; Patelli \& Pedrini, 2015). All of the employees in an organization can follow SM's actions and mindset for the prevention of fraud (Weber, 2010; Bruisnsma \& Wemmenhove 2009; Akkeren \& Buckby, 2017).

SM provides the surety that strategic planning is aligned with the objectives of the organization (Mod-Sanusi et al., 2015). Strategic plans are endorsed by ARC and approved by the board of directors. SM must implement the strategic plan to achieve organizational goals and objectives and to achieve the true meaning of corporate governance. GCG establishes the segregation of duties between the board of directors and SM (Mod-Sanusi et al., 2015). Organizations which demonstrated the poor corporate governance usually have the same person as head of an organization and also the chairman of the board of directors (Keasey, Thomson \& Right, 2012). Furthermore, and to achieve shareholder satisfaction, GCG obliges organizations to adopt a two-tier system namely board of directors and SM, where shareholders appoint the board, and SM is appointed by the board (Korine \& Gomez, 2014).

It is one of the significant duties of SM to develop, implement and monitor corporate strategy which is required for the attainment of organizational goals. SM also has to accept the gaps and flaws identified in the strategic system, and they should be ready to amend it as and when identified and reported. SM is a combination of executive people who are liable for the organizational performance (e.g., CEO, CFO, and COO). $S M$ reviews the corporate strategy periodically intending to identify any gaps between actual performance and objectives; moreover, SM has to discuss the strategy of the organization following every three years (COSO, 2016; Bentley-Goode, Newton \& Thompson, 2017) for assuring its practicality and continuous alignment with corporate objectives.

\section{Fraud risk assessment}

FRA is a major part of fraud risk management and is a core element for the achievement of GCG (Singleton \& Singleton, 2010). FRA deals with the risks which are directly attributable to fraud, its impact and its prospect of occurring. FRA contributes to GCG by becoming part of the governance structure of an organization in the shape of written policies as these policies express the expectation of the board of directors (Law, 2011). These policies are approved by the board and SM is obligated for its implementation. FRA drafts a mechanism which assesses the SM function not only for the implementation of policies but also monitor their compensation, performancebased bonuses, and un-authorized related parties transactions. FRA creates tones at the top by ongoing compliance and mitigating program (KPMG, 2014). FRA also obliges ARC to perform the task effectively towards fraud and related risk by reviewing the policies and updating them as and when required. FRA also assists ARC towards the resolution of internal and external audit observations and the implementation of their approved recommendations.

FRA is a control that identifies important and integral fraud risk and paves the way for the achievement of GCG (Law, 2011). FRA documents the schemes of fraud that occurred in the past and occurred within a similar industry. FRA is scheme and scenario-based rather than inherent and control based and therefore provides better control towards the prevention of fraud and assists in the achievement of organizational goals. FRA offers complete guidance for ARC and SM for the policies, which can be impacted by the fraud and its related activities (Vona, 2010), and at the 
same time, FRA assesses the effectiveness of ARC and SM (Siregar \& Tenoyo, 2015). Furthermore, FRA is a continuous and ongoing approach, and it's not a one-off exercise that also assesses the code of conduct, its process, and its implementation.

FRA is dependent upon several factors and elements. These elements are measured on the scale of occurrence and its related impact on the organization. These scales are often referred to as heat maps (Anderson, 2011). The inclusion of FRA is becoming a necessary part of all sorts of audits. Additional auditing standards are introduced to cater to the FRA by the American Institute of Certified Public Accountants and Institute of Internal Auditors.

For the achievement of effective FRA, Table 2 defines factors which should be considered (Singleton \& Singleton 2010): These factors can be notified at different levels such as people, divisions, products or services, accounting or business process and controls.

Table 2

Factors of Effective Fraud Risk Assessment

\begin{tabular}{ll}
\hline Factors & Description \\
\hline Corporate environment factor & $\begin{array}{l}\text { Specific industries are more susceptible to fraud and } \\
\text { thus require more controls. }\end{array}$ \\
\hline $\begin{array}{l}\text { Internal factors } \\
\text { Fraud factors } \\
\text { fraud. }\end{array}$ \\
$\begin{array}{l}\text { This factor identifies the fraud schemes which can be } \\
\text { inferred by employees or outside organizations }\end{array}$ \\
\hline
\end{tabular}

Source: Singleton and Singleton (2010)

Effective FRA can result in minimized financial losses due to fraud, decreasing the cost of responding to fraud, enhancing compliance with local regulations, improving employee awareness, increasing in potential reporting of fraud (whistleblowing), and resulting in more effective corporate governance (Abdullahi \& Mansor, 2015; Abdullatif, 2013; Leonard, 2010) with the potential of achieving GCG.

\section{Corporate governance in Oman}

Corporate governance concept is new in Oman and like any other country; Oman is not safe from fraudulent activities. In the last five years, few of the reported cases of fraud are ranging from USD 39 million to USD 2.6 million (Mukrashi, 2016; Reuter, 201 1; Reuter, 2013; Reuter, 2014) and spread around various industries or sectors. However, the majority are falling under the fraud category of ethical misconduct. By World Bank (2016), the governance score of Oman for the year 2016 related to control of corruption is almost constant of the score achieved in 2006, moreover by ACFE (2016) number of reported fraud cases in Oman is increasing every year. The reason for such fraudulent activities is lack of oversight by the board of directors and lack of ethical culture developed by SM, and due to this reason, governance plays a reduced role towards control of fraud and corruption (Halbouni, Nada \& Abeer, 2016).

In Oman, new codes of corporate governance are implemented in the year 2016 , whereas former codes were adopted in 2002. These new codes still require certain amendments and modifications to cater for the achievement of GCG and to provide satisfaction to shareholders. There are one hundred and fifteen companies listed in Muscat Stock Market (MSM) and distributed under the financial, industrial and service sectors. Public listed companies are governed by Commercial Companies Law, Capital Market Rules and codes of corporate governance. 


\section{Methodology}

A descriptive cross-sectional survey design along with the quantitative research method approach was utilized to identify the relationship between FRA and GCG. The unit of analysis is Omani public listed companies. For this study, five-point Likert scale logic was utilized ranging from highly agree to highly disagree, and questions were distributed into different sections for FRA, ARC, and SM. These sections explain the definition and define the significant element of GCG as ARC and SM. Due to the small population size, census sampling was utilized and the contribution of all 115 companies was taken into consideration.

Questions in Table 3 related to ARC and SM deals with all the major factors or elements required for the achievement of GCG. Organizations are obliged to follow the basic requirements of corporate governance, which include conducting the meetings of ARC. Nevertheless, it is the effectiveness of the meetings of ARC, which should be minuted and defines the proceedings and instructions of ARC (Mohd-Sanusi et al., 2015). Similarly, ARC performs an essential role in strategic planning which leads towards the achievement of goals and objectives and provides enhanced corporate governance (Krishnan \& Lee, 2008), which can be termed as GCG. ARC operates like the board's advisor; however, the assistance of internal and external audit is required. These two independent departments perform the tasks, provide information to ARC towards achievements of organizational goals, and define recommendations. ARC has to discuss the extensiveness, pervasiveness and commonness of audit findings and related recommendations in audit reports with senior management (Laura et al., 2010; Laux \& Laux, 2009) enabling the achievement of GCG. For SM, the questionnaire covers the area of strategic planning, objectives and corrective actions. These are the three main elements of the accomplishment of GCG as they are directly linked with organizational goals and affect organizational performance.

Questions in Table 3 related to FRA cover all the aspects, which can be considered necessary for the FRA for the achievement of GCG. Following the ACFE (2016), the significant aspects of fraud risk governance which can enhance the organizational corporate governance are effective tone at the top which can also be defined as ethics and code of conduct policies (Siregar \& Tenoyo, 2015), whistleblowing policy and protection of whistleblower, assessment of executive management and evaluation of audit committee. These questions are comprehensive and widespread, covering the areas of corporate governance, which can ultimately lead towards the attainment of GCG.

Respondents were requested to answer fifteen questions, including three related to demographics. The respondents included in this study are members of the board of directors and its related committees, company secretaries, SM and internal auditors. Data was collected with the assistance of Internet-based application and analysis was conducted by utilizing Statistical Package for Social Science (SPSS) and Partial Least square and Structural Equation Modeling (PLS-SEM).

For the assessment of the measurement model, internal consistency and reliability are measured by utilization of composite reliability (Henseler, Ringle, \& Sarstedt, 2015; Ramayah, Cheah, Chuah, Ting \& Memon, 2018). Assessment of convergent validity is conducted via average variance extracted (AVE) and assessment of discriminant validity is conducted with Heterotrait-monotrait (HTMT) ratio. Assessment of AVE, composite reliability (CR) and discriminant validity can be categorized as the evaluation of measurement model (Henseler et al., 2015; Hair, Hult, Ringle, \& Sarstedt, 2017). Acceptable values for AVE, CR and discriminant validity are defined by Ramayah et al., (2018) and presented in Table 4. 
Table 3

Research instrument

\begin{tabular}{|c|c|c|c|}
\hline Code & The question used in research & $\begin{array}{l}\text { Adopted/ } \\
\text { Adapted }\end{array}$ & Original question \\
\hline \multicolumn{4}{|c|}{ Good Corporate Governance - Audit and Risk Committee; Source Mohd-Sanusi et al., 2015} \\
\hline ARC.4.B.1 & $\begin{array}{l}\text { My company's audit and risk } \\
\text { committee meetings are held } \\
\text { regularly and minuted, with } \\
\text { actions noted by new codes of } \\
\text { corporate governance issued by } \\
\text { the capital market authority }\end{array}$ & Adapted & $\begin{array}{l}\text { Board's meetings were } \\
\text { held regularly and } \\
\text { minuted, with actions } \\
\text { noted }\end{array}$ \\
\hline ARC.4.B.2 & $\begin{array}{l}\text { My company's audit and risk } \\
\text { committee discuss the } \\
\text { pervasiveness of audit findings/ } \\
\text { recommendations in audit reports } \\
\text { with senior management. }\end{array}$ & Adapted & $\begin{array}{l}\text { Board Discuss } \\
\text { reasonableness of audit } \\
\text { finding/recommendation } \\
\text { in audit reports with } \\
\text { management }\end{array}$ \\
\hline ARC.4.B.3 & $\begin{array}{l}\text { My company's audit and risk } \\
\text { committee ensure that strategic } \\
\text { planning is in line with the } \\
\text { organization's objectives. }\end{array}$ & Adapted & $\begin{array}{l}\text { Strategic planning has a } \\
\text { clear relationship with the } \\
\text { organization's objectives }\end{array}$ \\
\hline \multicolumn{4}{|c|}{ Good Corporate Governance - Senior Management; Source Mohd-Sanusi et al., 2015} \\
\hline SM.4.D.1 & $\begin{array}{l}\text { In my company, there is strategic } \\
\text { planning lasting three years or } \\
\text { more }\end{array}$ & Adapted & $\begin{array}{l}\text { There is strategic planning } \\
\text { lasting three years or more } \\
\text { and is updated annually. }\end{array}$ \\
\hline SM.4.D.2 & $\begin{array}{l}\text { My company's strategic planning } \\
\text { has a clear relationship with the } \\
\text { organization's objectives }\end{array}$ & Adapted & $\begin{array}{l}\text { The strategic plan has a } \\
\text { clear association with the } \\
\text { organization's goals. }\end{array}$ \\
\hline SM.4.D.3 & $\begin{array}{l}\text { Senior management of my } \\
\text { company seriously views } \\
\text { corrective actions as an avenue } \\
\text { for improvements }\end{array}$ & Adopted & $\begin{array}{l}\text { Senior management of my } \\
\text { company seriously sees } \\
\text { corrective actions as an } \\
\text { avenue for improvements }\end{array}$ \\
\hline \multicolumn{4}{|c|}{ Fraud Risk Assessment; Source: Siregar and Tenoyo (2015) } \\
\hline FRA.C.3.6.1 & $\begin{array}{l}\text { In my company, ethics policy } \\
\text { should be assessed by fraud risk } \\
\text { assessment }\end{array}$ & Adapted & $\begin{array}{l}\text { Good fraud risk } \\
\text { management covers } \\
\text { ethics policy }\end{array}$ \\
\hline FRA.C.3.6.2 & $\begin{array}{l}\text { In my company, the code of } \\
\text { conduct should be assessed by } \\
\text { fraud risk assessment }\end{array}$ & Adapted & $\begin{array}{l}\text { Good fraud risk } \\
\text { management covers the } \\
\text { code of conduct }\end{array}$ \\
\hline FRA.C.3.6.3 & $\begin{array}{l}\text { In my company, well-defined } \\
\text { whistleblowing policy should be } \\
\text { assessed by fraud risk assessment }\end{array}$ & Adapted & $\begin{array}{l}\text { Good fraud risk } \\
\text { management covers } \\
\text { whistleblowing policy }\end{array}$ \\
\hline FRA.C.3.6.4 & $\begin{array}{l}\text { In my company, useful senior } \\
\text { management function should be } \\
\text { assessed by fraud risk assessment }\end{array}$ & Adapted & $\begin{array}{l}\text { Good fraud risk } \\
\text { management covers } \\
\text { useful board function }\end{array}$ \\
\hline FRA.C.3.6.5 & $\begin{array}{l}\text { In my company, effective audit } \\
\text { and risk committee should be } \\
\text { assessed by fraud risk assessment }\end{array}$ & Adapted & $\begin{array}{l}\text { Good fraud risk } \\
\text { management covers } \\
\text { effective board function }\end{array}$ \\
\hline FRA.C.3.6.6 & $\begin{array}{l}\text { My company has a system in } \\
\text { place for reporting of suspicions of } \\
\text { fraud and misconduct }\end{array}$ & Adopted & $\begin{array}{l}\text { Good fraud risk } \\
\text { management includes a } \\
\text { system for reporting of } \\
\text { suspicions of fraud and } \\
\text { misconduct }\end{array}$ \\
\hline
\end{tabular}

Source: Authors' work 
Table 4

Acceptable values- measurement model analysis

\begin{tabular}{|c|c|c|}
\hline Assessment & Index Name & Acceptable Value \\
\hline Internal Consistency & CR & Composite reliability $\geq 0.70$ \\
\hline $\begin{array}{l}\text { Indicator } \\
\text { reliability/Factor } \\
\text { Loadings }\end{array}$ & Indicator Loading & $\begin{array}{l}\text { Values below } 0.4 \text { should be deleted. } \\
\text { Loadings indicators }>0.7,0.6,0.5 \text { is } \\
\text { adequate. }\end{array}$ \\
\hline Convergent validity & $\begin{array}{l}\text { Average Variance } \\
\text { Extracted (AVE) }\end{array}$ & $\begin{array}{l}\text { Retained indicators should have AVE } \geq \\
0.50 \text {. Indicators }<0.5 \text { should be deleted }\end{array}$ \\
\hline Discriminant validity & HTMT & HTMT - all values must be $\leq 0.85$ \\
\hline
\end{tabular}

Source: Ramayah et al., (2018)

Structural model assessment is required once all the criteria of measurement model are met. Structural model assessment comprises of collinearity measurement, determination of path coefficient, $\mathrm{R}^{2}$ and $\mathrm{Q}^{2}$ (Hair et al., 2017). Table 5 defines the acceptable values related to the assessment of the structural model.

Table 5

Acceptable values for model evaluation- structural model analysis

\begin{tabular}{|c|c|c|}
\hline Assessment & Index Name & Acceptable Value \\
\hline Collinearity & $\begin{array}{l}\text { Variance inflator } \\
\text { factor (VIF) }\end{array}$ & $\begin{array}{l}\text { VIF values for specific indicators should } \\
\text { be }>5\end{array}$ \\
\hline Path Coefficient & Path Coefficient & $\begin{array}{l}\text { p-value }<0.01 \\
\text { t value }>2.33 \text { (one-tailed) }\end{array}$ \\
\hline $\mathbf{R}^{2}$ & $\begin{array}{l}\text { Coefficient of } \\
\text { determination }\end{array}$ & $\begin{array}{l}\text { 0.26- Substantial } \\
0.13 \text { - Moderate } \\
0.02 \text { - Weak }\end{array}$ \\
\hline $\mathbf{Q}^{2}$ & $\begin{array}{l}\text { Q2 predictive } \\
\text { relevance (Stone } \\
\text { Geisser) }\end{array}$ & $\begin{array}{l}\text { A value greater than zero specifies that } \\
\text { the independent variable has predictive } \\
\text { relevance over the dependent variable }\end{array}$ \\
\hline
\end{tabular}

Source: Hair et al., (2017)

\section{Results}

Responses were received from 110 organizations, which make up to $96 \%$ of the population. The response rate is consistent with the other studies where census sampling was utilized but the response rate was not 100\% (Yeboah, Kwafoa, \& Amoah, 2017). The analysis was performed on 107 responses as three respondents did not complete the entire questionnaire. These three respondents are considered as missing data and therefore taken out of the study.

The demographic profile of 110 respondents is presented in Table 6. $95 \%$ of the respondents were male, whereas only $5 \%$ were the female respondents. For the qualification, $46 \%$ of respondents were having professional qualifications followed by the Master's qualification which is $33 \%$. Other qualifications include a degree in law and chartered secretary certifications. $66 \%$ of respondents belong to the role of SM, followed by ARC members which are $15 \%$. The lowest percentage of respondents was from the remuneration committee. 
Table 6

Demographic profile of respondents

\begin{tabular}{llll}
\hline Category & Description & $\begin{array}{l}\text { Number of } \\
\text { Respondents }\end{array}$ & \%age \\
\multirow{2}{*}{ Gender } & Male & 106 & 96 \\
\multirow{2}{*}{ Highest Qualification } & Female & 4 & 4 \\
& CA/ CPA/ MIPA/ CIA/ CRMA & 51 & 46 \\
& CFE or other fraud-related education & 3 & 3 \\
& Masters & 36 & 33 \\
& Bachelors & 13 & 12 \\
Role/ Position in & Others & 7 & 6 \\
Organization & Board of Director & 14 & 13 \\
& Audit and Risk Committee & 17 & 15 \\
& Remuneration Committee & 6 & 5 \\
& Senior Management & 73 & 66 \\
\hline
\end{tabular}

Source: Authors' work

The measurement model was assessed by utilizing PLS-SEM and by following the acceptable values defined by Ramayah et al., (2018) which are presented in Table 4. All indicators or questions are retained as outer loading for all of them was 0.5 and above. Outer loading defines the relationship between reflective construct and measured indicators. The average variance extracted (AVE) of GCG is 0.542 and composite reliability (CR) of GCG is 0.875. AVE of FRA is 0.818 and CR of FRA is 0.964 . AVE and CR values are reported in Table 7; moreover, values of HTMT ratio is below 0.85 .

Table 7

Outer loading, average variance extracted and composite reliability

\begin{tabular}{|c|c|c|c|}
\hline Variable and Question Code & $\begin{array}{l}\text { Outer } \\
\text { Loading }\end{array}$ & $\begin{array}{l}\text { Average } \\
\text { Variance } \\
\text { Extracted }\end{array}$ & $\begin{array}{l}\text { Composite } \\
\text { Reliability }\end{array}$ \\
\hline \multicolumn{4}{|c|}{ Good Corporate Governance (GCG) } \\
\hline ARC.4.B.1 & 0.685 & \multirow{6}{*}{0.542} & \multirow{6}{*}{0.875} \\
\hline ARC.4.B.2 & 0.581 & & \\
\hline ARC.4.B.3 & 0.659 & & \\
\hline SM.4.D.1 & 0.858 & & \\
\hline SM.4.D.2 & 0.803 & & \\
\hline SM.4.D.3 & 0.796 & & \\
\hline \multicolumn{4}{|c|}{ Fraud Risk Assessment (FRA) } \\
\hline FRA.C.3.6.1 & 0.88 & \multirow{6}{*}{0.818} & \multirow{6}{*}{0.964} \\
\hline FRA.C.3.6.2 & 0.91 & & \\
\hline FRA.C.3.6.3 & 0.88 & & \\
\hline FRA.C.3.6.4 & 0.92 & & \\
\hline FRA.C.3.6.5 & 0.94 & & \\
\hline FRA.C.3.6.6 & 0.55 & & \\
\hline
\end{tabular}

Source: Authors' work

Structural model assessment can be conducted now as the requirements for the measurement model are met, as presented in Table 7.

The assessment of the structural model was conducted following the information available in Table 5. For collinearity assessment, the result suggests that the value of VIF is one; therefore, there is no problem of multi-collinearity (Carbonell, Alcázar, \& Gardey, 2015). The value of $R^{2}$ is 0.121 and the value of $Q^{2}$ is 0.051 . Both $R^{2}$ and $Q^{2}$ values are meeting the acceptance criteria (Hair et al., 2017). 
For the significance of the direct effect-path coefficient, the application of bootstrapping was utilized with 5000 sub-samples for the 107 respondents. Acceptable values for the path coefficients are available in Table 5 (Hair et al., 2017). Table 8 defines that significance of direct effect - path coefficients:

Table 8

The significance of Direct Effect - Path Coefficients

\begin{tabular}{lllllll}
\hline Relationship & Beta $(\boldsymbol{\beta})$ & $\begin{array}{l}\text { Standard Error } \\
(\text { STDEV) }\end{array}$ & $\begin{array}{l}\text { T Statistics } \\
(\boldsymbol{\beta} / \text { STDEV) }\end{array}$ & P Values & $\mathbf{R}^{2}$ & $\mathbf{Q}^{2}$ \\
\hline FRA $\rightarrow$ GCG & 0.348 & 0.104 & $3.351^{* * *}$ & 0.00 & 0.121 & 0.051 \\
\hline
\end{tabular}

Note: ${ }^{* * *} p<0.01$ ( $\left.+>2.33\right)$ (One Tail)

It is evident from the result presented in Table 8 that beta (original mean) is 0.348 which is positive, the t-value is 3.351 and the $p$-value is 0.00 . Positive beta demonstrates that the relationship is direct, whereas t-values more than 2.33 and $p$-values less than 0.05 demonstrate the significance of the result. Henceforth, it is ascertained that FRA is positively statistically significant and influencing GCG. The arrived result is in coherence with the literature review, where it is mentioned that FRA can influence GCG. The influence of FRA on GCG is in the form of policies and procedures by implementing risk registers, risk profiles, their likelihood, and related impact.

\section{Conclusion}

FRA is the cornerstone of good corporate governance and can be considered as vital control towards the elimination of fraud within an organization. FRA is a control that can be available in the form of policies and procedures. Frauds can be identified before its occurrence and mitigating factors can be developed once FRA is properly developed and implemented. Concurrently, GCG can operate effectively once the organization is free from fraud and fraudulent activities. Fraud free environment also enables GCG to provide satisfaction to shareholders. For this study, GCG is measured by its two main constituents, namely ARC and SM.

This paper is intended to identify the relationship of fraud risk assessment with good corporate governance for the companies listed in the Muscat Stock Market in the Sultanate of Oman. For this reason, a quantitative survey was performed for all one hundred and fifteen organizations listed in MSM, from which $93 \%$ of respondents were analyzed and assessed. The questionnaire was only forwarded to the board of directors and related committee members and SM as they possess the knowledge of the organization and can respond on behalf of the organization. The internet-based tool was utilized to collect the data and it was analyzed by the utilization of PLS-SEM and SPSS. The result of this study proposes that FRA is having a direct and significant relationship with GCG as the t value is 3.351 and the p-value is 0.00 .

This study makes meaningful participation in the literature review and also provides practical application to organizations. Practical application cannot only limit to the Omani public listed companies but can be applicable for all organizations across the globe. GCG is the fundamental requirement for all organizations and can be considered for organizations other than public listed companies such as private and government-owned companies. Similarly, fraud is also impacting all organizations regardless of its categorization; therefore the implementation of FRA is essential towards elimination, mitigation and controlling of fraud.

There are two limitations to this study. Firstly this study is only directed towards public listed companies; there are only 115 public listed companies in Oman and inclusion of private limited companies with paid-up share capital of USD 10 million or more would 
have provided better results. However, the scope of this study is only limited to public listed companies. For research limitation, this study is conducted at the firm level where one individual replied on behalf of the organization; however, the responses of at least three respondents could have enhanced the result and provides a better situation of the organization towards FRA and GCG.

\section{References}

1. Abbot, L., Park, Y., Parker, S. (2000), "The effects of audit committee activity and independence on corporate fraud", Managerial Finance, Vol. 26 No. 11, pp. 55-68.

2. Abdel-Meguid, A., Samaha, K., Dahawy, K. (2014), "Preliminary evidence on the relationship between corporate governance attributes and audit committee functionality in Egypt: beyond checking the box", Corporate Governance, Vol. 14 No. 2, pp. 197-210.

3. Abdullahi, R., Mansor, N. (2015), "Forensic Accounting and Fraud Risk Factors: The Influence of Fraud Diamond Theory", European Journal of Business and Management. Vol. 7 No. 28, pp. 30-37.

4. Abdullatif, M. (2013), "Fraud Risk Factors and Audit Programme Modifications: Evidence from Jordan", Australasian Accounting, Business and Finance Journal. Vol. 7 No. 1, pp. 5977.

5. ACFE (2016), " Report to the nations on occupational fraud and abuse: 2016 global fraud study ", Association of Certified Fraud Examiners, Chicago.

6. Akkeren, J. V., Buckby, S. (2017), "Perceptions on the Causes of Individual and Fraudulent Co-offending: Views of Forensic Accountants", Journal of Business Ethics, Vol. 146 No. 2, pp. 383-404.

7. Al-Moataz, E. S. (2003), "The Effectiveness of Audit Committees within Saudi Corporations: An Empirical Investigation", Ph.D. Thesis, Business School Loughborough University, London, UK.

Available at https://dspace.lboro.ac.uk/dspace-jspui/bitstream/2134/6972/3/15417.pdf (12 November 2018)

8. Anderson, R. (2011), "Risk management and corporate governance", Organization for Economic Co-Operation and Development (OECD).

9. Bentley-Goode, K. A., Newton, N. J., Thompson, A. M. (2017), "Business Strategy, Internal Control over Financial Reporting, and Audit Reporting Quality", Auditing: A Journal Of Practice \& Theory Vol. 36 No. 4, pp. 49-69.

10. Bhasin, M. L. (2013), "Corporate Governance and Forensic Accountant: an Exploratory Study", Journal of Accounting - Business Management, Vol. 20 No. 2, pp. 35-49.

11. Brennan, N. M., McGrath, M. (2007), "Financial statement fraud: Some lessons from US and European case studies", Australian Accounting Review, Vol. 17 No. 2, pp. 49-61.

12. Bruisnsma, C., Wemmenhove, P. (2009), "Tone at the top is vital! A Delphi study", ISACA Journal, Vol. 3, pp. 1-4.

13. CMA (2016), "Oman Code of Corporate Governance for Public Listed Companies", Capital Market Authority, Muscat.

14. COSO (2016), "Enterprise Risk Management: Aligning risk with strategy performance", Committee of Sponsoring Organizations of the Treadway Commissions (COSO).

15. Efiong, E. J. (2012), "An exploration of forensic accounting education and practice for fraud prevention and detection in Nigeria", International Journal of Business and Management, Vol. 7 No 4, pp. 26-34.

16. García, L. S., Barbadillo, E. R., \& Pérez, (2010), "Audit committee and internal audit and the quality of earnings: empirical evidence from Spanish companies", Journal of Management Governance, Vol. 16 No. 2, pp. 305-331.

17. Gatzert, N., Schmit, J. T., Kolb, A. (2016), "Assessing the Risks of Insuring Reputation Risk", Journal of Risk Insurance, Vol. 83 No. 3, pp. 641-679.

18. Hair, J. F., Hult, G. T., Ringle, C. M., Sarstedt, M. (2017), "A Primer on Partial Least Squares Structural Equation Modeling (PLS-SEM)", Sage, New York. 
19. Halbouni, S. S., Nada, O., Abeer, G. (2016), "Corporate governance and information technology in fraud prevention and detection: Evidence from the UAE", Managerial Auditing Journal Vol. 31 No. 6/7, pp. 589-628.

20. Hashim, F., Mahadi, N. D., Amran, A. (2015), "Corporate Governance and Sustainability Practices in Islamic Financial Institutions: The Role of Country of Origin", Procedia Economics and Finance Vol. 31, pp. $36-43$

21. Henseler, J., Ringle, C. M., Sarstedt, M. (2015), "A new criterion for assessing discriminant validity in variance-based structural equation modeling", Journal of the academy of marketing science, Vol. 43 No. 1, pp.115-135.

22. Hoitash, R., Hoitash, U. (2009), "The role of audit committees in managing relationships with external auditors after SOX: Evidence from the USA", Managerial Auditing Journal, Vol. 24 No. 4, pp. 368-397.

23. Homayara, L. A., Md. Jahangir, A., Saeed, A. J., Sawlat, H. Z. (2008), "A Conceptual Review on Corporate Governance and its Effect on Firm's Performance: Bangladesh Perspective", AIUB Bus Econ Working Paper Series AIUB-BUS-ECON-2008-10, American International University-Bangladesh (AIUB), Office of Research and Publications (ORP), revised Mar 2008.

24. Keasey, K., Thomson, S., Right, M. (2012), "Corporate governance, economic, management, and financial issues", Oxford press University, Oxford.

25. Korine, H., Gomez, Y. P. (2014), "Strong managers, strong owners: Corporate Governance and Strategy", Cambridge University Press, London

26. KPMG (2014, May), "Fraud risk management Developing a strategy for prevention, detection, and response" Available at https://assets.kpmg/content/dam/kpmg/pdf/2014/05/fraud-risk-management-strategyprevention-detection-response-O-201405.pdf (15 July 2018)

27. Krishnan, J., Lee, J. E. (2009), "Audit committee financial expertise, litigation risk, and corporate governance", Auditing: A Journal of Practice \& Theory, Vol. 28 No. 1, pp. 241261.

28. Laux, C., Laux, V. (2009), "Board committees, CEO compensation, and earnings management", The Accounting Review, Vol. 84 No. 3, pp. 869-891.

29. Law, P. (2011), "Corporate governance and no fraud occurrence in organizations: Hong Kong evidence", Managerial Auditing Journal, Vol. 26, pp. No. 6, pp. 501-518.

30. Mohd-Sanusi, Z., Rameli, M. N., Omar, N., Ozawa, M. (2015), "Governance mechanisms in the Malaysian Banking Sector: Mitigation of Fraud Occurrence", Asian Journal of Criminology, Vol. 10 No. 3, pp. 231-249.

31. Mukrashi, F. A. (2016), "Oman's National Gas Company fires CEO over bribery" Available at http://gulfnews.com/news/gulf/oman/oman-s-national-gas-company-fires-ceo-overbribery-1.1674858 (19 August 20181)

32. Nwagbara, U. (2012), " En/countering corrupt leadership and poor corporate governance in the Nigerian banking sector: Towards a model of ethical leadership ", Indian Journal of Corporate Governance, Vol. 5 No. 2, pp. 133-148.

33. Oso, L., Semiu, B. (2012), "The concept and practice of corporate governance in Nigeria: The need for public relations and effective corporate communication", Journal of Communication, Vol. 3 No. 1, pp. 1-16.

34. Patelli, L., Pedrini, M. (2015), "Is tone at the top associated with financial reporting aggressiveness", Journal of Business Ethics, Vol. 126 No. 1, pp. 3-19.

35. Pintea, M. O., Fulop, M. T. (2015), "Corporate Governance - Key Factor to Enhance Performance. Managerial Challenges of the Contemporary Society". Vol. 8 No. 2, 116-120.

36. Ramayah, T., Cheah, J., Chuah, F., Ting, H., Mumtaz A., M. (2018), Partial Least Squares Structural Equation Modeling (PLS-SEM) Using SmartPLS 3.0: An Updated Guide and Practical Guide to Statistical Analysis. Pearson, Kuala Lumpur.

37. Rehman, A., Hashim, F. (2018), "Literature Review: Preventive Role of Forensic Accounting and Corporate Governance Maturity", Journal of Governance and Integrity (JGI), pp. 6893.

38. Rehman, A., Hashim, F. (2019), "Impact of Mature Corporate Governance on Detective Role of Forensic Accounting: Case of Public Listed Companies in Oman" in FGIC 2nd Conference on Governance and Integrity 2019, KnE Social Sciences, pp. 637-665. 
39. Reuter, S. (2013), "Oman's Bank Muscat hit by $\$ 39 \mathrm{mln}$ prepaid card fraud". Available at https://www.reuters.com/article/oman-bankmuscat-fraud/omans-bank-muscat-hit-by-39mln-prepaid-card-fraud-idUSL6NOBQ1C720130226 (25 December 2018)

40. Reuters, S. (2011), "Oman's Renaissance uncovers fraud at Topaz unit, H1 profit falls". Available at https://www.reuters.com/article/us-renaissance-results/omans-renaissanceuncovers-fraud-at-fopaz-unit-h1-profit-falls-idUSTRE77EONW201 10815 (25 December 2018)

41. Reuters, S. (2014), "Oman court jails businessman to 15 years over bribes". Available at https://www.reuters.com/article/us-oman-corruption-sentences/oman-court-jailsbusinessman-to-15-years-over-bribes-idUSBREA280I020140309 (25 December 2018)

42. Rezaee, Z., Lo. D., Ha, M., Suen, A. (2016), "Forensic Accounting Education and Practice: Insights from China", Journal of Forensic Investigative Accounting, Vol. 8 No. 1, pp. 23-34.

43. Saud, S., Marchand, N. (2012), "Contribution of internal audit in the achievement of corporate goals" A Case of Sweden and Pakistan", (Master's Thesis; Business Administration Karlstad Business School. Sweden) available at http://www.divaportal.org/smash/get/diva2:537276/fulltext01 (19 October 2018).

44. Shir, L. N. (2013), "Role Effectiveness of Audit Committees' Governance Characteristics: Impacts on Internal and External Auditing of Listed Companies" (Ph.D. Thesis, School of Accounting College of Business RMIT University, Australia), Available at https://researchbank.rmit.edu.au/view/rmit:160435 (25 June 2018)

45. Singleton, T., Singleton, A. (2010), "Fraud Auditing and Forensic Accounting 4th Edition", John Wiley Sons, Chicago.

46. Siregar, S. V., Tenoyo, B. (2015), "Fraud awareness survey of the private sector in Indonesia", Journal of Financial Crimes, Vol. 22 No. 3, pp.329-346.

47. Stewart, J., Munro, L. (2007), "The Impact of Audit Committee Existence and Audit Committee Meeting Frequency on the External Audit: Perceptions of Australian Auditors", International Journal of Auditing Vol. 11, pp. 51-69.

48. Vona L.W. (2010), "The Fraud Audit: Responding to the Risk of Fraud in Core Business Systems", John Wiley and Sons, New York.

49. Wilbanks, R. M., Hermanson, D. R., Vineeta, D. S. (2017), "Audit Committee Oversight of Fraud Risk: The Role of Social Ties, Professional Ties, and Governance Characteristics", American Accounting Association: Accounting Horizons Vol. 31 No. 3, pp. 21-38.

50. Wilkinson, N. (2014, March), "A framework for organizational governance maturity: an internal audit perspective", South Africa: (Ph.D. Thesis, University of Pretoria. South Africa), Available https://repository.up.ac.za/bitstream/handle/2263/43563/Wilkinson_Framework_2014.pdf;s equence $=4$ (18 March 2018)

51. Wilkinson, N., Plant, K. (2012), "A framework for the development of an organizational governance maturity model: a tool for internal auditors", Southern African Journal of Accountability and Auditing Research, Vol. 13 No. 1, pp. 19-31.

52. World Bank, (2016), "Worldwide Governance Indicators" Available at www.databank.worldbank.org:

http://databank.worldbank.org/data/reports.aspx?source=worldwide-governanceindicators (26 March 2018)

53. Yeboah, E. B., Kwafoa, P., Amoah, G. B. (2017), "Security of Staff in Academic Libraries: A Study of Sam Jonah Library, University of Cape Coast", Journal of Applied Information Science, Vol. 05 No. 1, pp. 155-165.

54. Zakaria, N. B. (2012), "Corporate Governance And The Relationship Between Default Risk and The Earnings Response Coefficient" (Ph.D. thesis Victoria University of Wellington, New Zealand): available at http://researcharchive.vuw.ac.nz/bitstream/handle/10063/2106/thesis.pdf? sequence=1 (15 February 2018) 


\begin{abstract}
About the authors
Ali Rehman, Ph.D. is Internal Audit Director at A'Sharqiyah University. He received a PhD in Governance and Risk Management at the Universiti Sains Malaysia with the dissertation thesis "Forensic Accounting on Corporate Governance Maturity; Case of Public Listed Companies in Oman". He is also professionally certified as ACMA, CGMA, CIA, CRMA, and MIPA. The author can be contacted at ali.rehman@asu.edu.om

Fathyah Hashim, is currently working as Senior Lecturer in Graduate School of Business, Universiti Sains Malaysia. She received DBA from Universiti Kebangsaan Malaysia, and her research interest areas are voluntary disclosure, intellectual capital, R\&D and corporate social responsibility disclosure. The author can be contacted at fathashim@usm.my
\end{abstract}

